\title{
Euthanasia in patients dying at home in Belgium: interview study on adherence to legal safeguards
}

Tinne Smets, Johan Bilsen, Lieve Van den Block, Joachim Cohen, Viviane Van Casteren and Luc Deliens

\author{
ABSTRACT \\ Background \\ Euthanasia became legal in Belgium in 2002. \\ Physicians must adhere to legal due care requirements \\ when performing euthanasia; for example, consulting a \\ second physician and reporting each euthanasia case \\ to the Federal Review Committee. \\ Aim \\ To study the adherence and non-adherence of GPs to \\ legal due care requirements for euthanasia among \\ patients dying at home in Belgium and to explore \\ possible reasons for non-adherence. \\ Design of study \\ Large scale, retrospective study. \\ Setting \\ General practice in Belgium. \\ Method \\ A retrospective mortality study was performed in \\ 2005-2006 using the nationwide Belgian Sentinel \\ Network of General Practitioners. Each week GPs \\ reported medical end-of-life decisions taken in all non- \\ sudden deaths of patients in their practice. GP \\ interviews were conducted for each euthanasia case \\ occurring at home. \\ Results \\ Interviews were conducted for nine of the 11 identified \\ euthanasia cases. Requirements concerning the \\ patient's medical condition were met in all cases. \\ Procedural requirements such as consultation of a \\ second physician were sometimes ignored. Euthanasia \\ cases were least often reported $(n=4)$ when the \\ physician did not regard the decision as euthanasia, \\ when only opioids were used to perform euthanasia, or \\ when no second physician was consulted. Factors that \\ may contribute to explaining non-adherence to the \\ euthanasia law included: being unaware of which \\ practices are considered to be euthanasia; insufficient \\ knowledge of the euthanasia law; and the fact that \\ certain procedures are deemed burdensome.

\section{Conclusion} \\ Substantive legal due care requirements for euthanasia \\ concerning the patient's request for euthanasia and \\ medical situation were almost always met by GPs in \\ euthanasia cases. Procedural consultation and \\ reporting requirements were not always met. \\ Keywords \\ euthanasia; health policy; terminal care.
}

\section{INTRODUCTION}

Medical end-of-life decisions, including euthanasia, are known to occur in several countries. ${ }^{1,2}$ Belgium is, along with the Netherlands and Luxembourg, one of the few countries where euthanasia is legal. ${ }^{3-6}$ It is often considered that, while the secrecy in which it takes place in countries where it is illegal prevents the development of guidelines and standards for careful practice, ${ }^{7,8}$ legalisation involves the creation of a regulatory system for societal control and the defining of a standard for careful medical practice..$^{3-6}$ Legalisation of euthanasia in Belgium included the establishment in the law of due care requirements (Box 1). ${ }^{3}$ For any law on euthanasia to be successful, it is a prerequisite that physicians who engage in the practice know and understand the due care requirements and adhere to them; to date, empirical information on adherence to the due care

T Smets, MA, junior researcher; J Cohen, $P h D$, senior researcher; J Bilsen, $R N, P h D$, professor of nursing sciences, End-of-Life Care Research Group, and Department of Public Health; L Van den Block, PhD, senior researcher and professor of communication and education in general practice, End-ofLife Care Research Group and Department of General Practice, Vrije Universiteit Brussel, Brussels, Belgium. V Van Casteren, $M D$, senior researcher, Scientific Institute of Public Health, Department of Epidemiology, Brussels, Belgium. L Deliens, $\mathrm{PhD}$, professor of public health and palliative care, End-of-Life Care Research Group, Vrije Universiteit Brussel, Brussels, Belgium and Department of Public and Occupational Health, EMGO Institute for Health and Care Research, Expertise Center for Palliative Care, VU University Medical Centre, Amsterdam, The Netherlands.

Address for correspondence

Tinne Smets, End-of-Life Care Research Group, Faculty of Medicine and Pharmacy, Laarbeeklaan 103, 1090 Brussels, Belgium.E-mail: tinne.smets@vub.ac.be

Submitted: 14 September 2009; Editor's response: 4 November 2009; final acceptance: 2 December 2009. (c) British Journal of General Practice

This is the full-length article of an abridged version published in print. Cite this article as: Br J Gen Pract 2010; DOI: 10.3399/bjgp10X483940. 
requirements of the euthanasia law in Belgium is lacking.

Information about euthanasia practice in Belgium is principally based on the cases of euthanasia officially reported by physicians to the Federal Review Committee. ${ }^{9-11}$ These data may not offer much insight into non-adherence, as physicians risk criminal prosecution if the Federal Review Committee determines that the law has been breached. Physicians may therefore be inclined to report only those cases where due care has been taken, or present their cases as compliant with the law. ${ }^{7}$ While large-scale epidemiological studies conducted in Flanders (the Dutch-speaking part of Belgium) provide information about the incidence of euthanasia and the decision-making process, ${ }^{1,12}$ they offer no in-depth insight into physicians' adherence and reasons for non-adherence to the legal due care requirements. After 7 years of legalised euthanasia, it is thus still unknown how it is actually practised by physicians in Belgium.

The present research therefore conducted indepth interviews with GPs shortly after a case of euthanasia, and investigated how they had experienced it and had dealt with the due care requirements. The study focused on cases in the home where the majority of euthanasia cases take place..$^{13}$ GPs have fewer guidelines for euthanasia, ${ }^{14}$ and less professional assistance available to them than physicians in hospitals, which makes investigating euthanasia by GPs in a home setting very relevant to identifying and understanding any problems they may encounter.

This article addresses the following research questions:

- To what extent do GPs adhere to the legal due care requirements for euthanasia when performing euthanasia at a patient's home?

- What are the possible reasons for non-adherence?

- How is euthanasia being performed and what drugs are used?

\section{METHOD}

\section{Study design, setting, and participants}

A large-scale retrospective mortality study was performed in 2005-2006 to monitor end-of-life care and decision making in Belgium, using the Sentinel Network of General Practitioners (SENTI-MELC study). ${ }^{15}$ It concerned a quantitative registration study of deaths in GP practices within the Belgian Sentinel Network, a surveillance network founded in 1979 which has proved to be a reliable surveillance system for a wide variety of health-related epidemiological data, ${ }^{15-17}$ and which is representative of all Belgian GPs in terms of age, sex, and region. ${ }^{18}$

\section{How this fits in}

An increasing number of states and countries are considering legalising

euthanasia. On 22 September 2002, Belgium became the second country in the

world to legalise euthanasia. Information about adherence and non-adherence

to the due care requirements of the euthanasia law is lacking. This study shows

that substantive legal due care requirements for euthanasia concerning the

patient's request for euthanasia and medical situation were almost always met

by GPs in cases of euthanasia, but procedural consultation and reporting

requirements were not always met.

The study resulted in a robust representative sample of non-sudden deaths $(n=1690)$ not restricted to a specific setting, age group, or disease (Figure 1). The study protocol has been published elsewhere. ${ }^{15}$

GPs registered deaths weekly and immediately after they learned of them, using a standardised form. ${ }^{15}$ From these it was possible to identify deceased patients who met the following inclusion criteria: aged $\geq 1$ year at the time of death; death did not occur 'suddenly or totally unexpectedly' as judged by the GP; and death occurred at home or in a care home. Based on these criteria, a large interview study was performed. The GPs involved in those cases meeting the inclusion criteria were contacted by telephone and asked to participate in an interview. This article reports only on the interviews involving home deaths registered by physicians as being the result of the 'administration

\section{Box 1. Legal due care requirements for euthanasia in Belgium.}

\section{Substantive requirements}

- The patient must be $\geq 18$ years.

- The patient's request must be voluntary and not the result of any external pressure, it must be well-considered and repeated, and must be put in writing.

- The patient must be in a condition of constant and unbearable physical or psychological suffering caused by illness or accident, for which medical treatment is unavailing and there is no possibility of improvement.

\section{Procedural requirements}

- The physician must inform the patient about his or her health condition and life expectancy, and together with the patient come to the belief that there is no reasonable alternative to the patient's situation.

- The physician must consult a second independent physician about the serious and incurable character of the illness; the physician must consult a third independent physician if the patient is not terminally ill.

- The physician must record the decision-making process in the patient's medical file.

- The physician must report the case of euthanasia to the Federal Control and Evaluation Committee Euthanasia for review. 


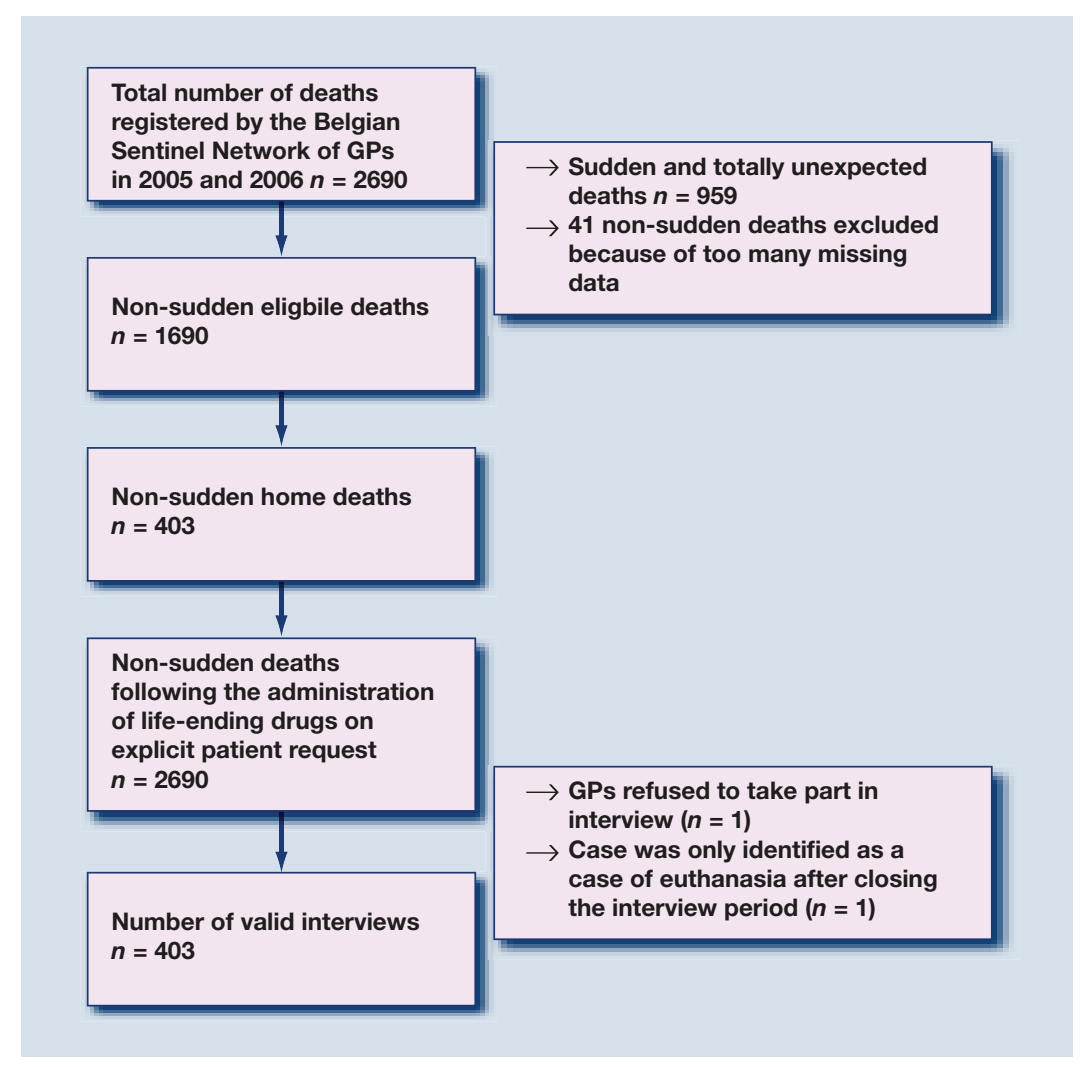

Figure 1. Selection of euthanasia cases. of a drug by someone other than the patient with the explicit intention of hastening the end of life on the explicit request of the patient': that is, euthanasia. No cases of euthanasia were reported in care homes.

\section{Measurements}

The interviews were face-to-face and semistructured and included both closed-ended and open-ended questions. Answers to open-ended questions were written down verbatim. For all questions there was room to note additional qualitative information given by the GP.

Interview questions were based largely on existing questionnaires (see Box 2 for interview topics). ${ }^{19-22}$ The questionnaire was first developed in Dutch and then translated into French via a backward-forward procedure.

\section{Procedure}

Strict procedures were used to preserve patient anonymity and physician confidentiality. Patient names were never identifiable to the interviewers or to other members of the research group: GPs used anonymous codes to refer to patients in the registration form, and before the interview the interviewers gave them closed envelopes with patient information, to make sure that the GP would give information about the correct patient. After the study, the identity of the GP was permanently deleted from all files. This precluded risk of criminal prosecution in case of non-compliance with the law. GPs were informed of these precautions so they could speak freely.

Several procedures were used to ensure data quality and avoid missing data. If the identity of a patient who died following the administration of a drug on their explicit request was left blank on the registration form, a follow-up letter was sent to the GP. To preclude overburdening the GP, no more than one interview of 1 hour maximum per 2 months per GP was done. This did not exclude any euthanasia cases, as no physician performed more than one euthanasia case within a 2-month period. In order to minimise recall bias, the interview was arranged as soon as possible after identification. Data-entry was done with consistency, range, and skip checks, and the answers to closed questions were entered twice.

\section{Analyses}

All closed-ended questions were descriptively analysed. Answers to open-ended questions and additional information given by GPs were encoded into categories by two researchers and/or registered as quotes. These were interpreted by the authors together with the project committee. Sociodemographic patient information was retrieved from the registration study.

\section{RESULTS}

Eleven euthanasia cases were registered in the 2-year study period. One GP refused to be interviewed, and one GP could not be interviewed about a euthanasia case registered during the 2-year study period because the registration form was only sent in by the GP after the interview period had closed. In nine of the 11 cases, it was possible to interview the GP. One of the interviewed physicians was responsible for two euthanasia cases (cases 1 and 8).

\section{Demographic and clinical characteristics of the euthanasia cases}

All nine patients who received euthanasia were adults, and none had a low level of education (Table 1). None was estimated as being of low income, and seven lived with a regular partner at the time of death. The main diagnosis was cancer $(n=7)$.

\section{Adherence to legal due care requirements for euthanasia}

Substantive requirements. All patients had made a voluntary and well-considered request for euthanasia (Table 2). Eight had put their request in writing. One patient (case 8) had only made their request verbally and the GP did not find it necessary that they should do this in writing because, 'there was a relationship of trust between me, the patient, and the family'. 
One patient (case 7) had made a request for euthanasia in writing but was persuaded by the GP to change this to a directive for palliative sedation. The GP indicated that they had 'explicitly intended to end the patient's life by administering a drug upon the patient's request', which is the definition of euthanasia in this study, but did not label this act as euthanasia but as 'terminal sedation with the explicit intention to hasten death'.

All patients were in a condition for which medical treatment was unavailing and there was no prospect of improvement. Most experienced lasting and unbearable physical and/or psychological suffering ( $n$ = 8); one patient (case 4) was not suffering unbearably at the end of the decision-making process, but unbearable suffering was expected in the future.

Procedural requirements. In all cases, the GP informed the patient about their health condition and life expectancy and in all cases they had together come to the conclusion that no more reasonable alternative treatments were possible. Sometimes the GP indicated that life-prolonging $(n=3)$ or palliative treatments $(n=4)$ were still possible, but they were not applied because the patient refused further treatment or did not want to prolong their life, or because the patient or physician deemed the chance for improvement too small.

In three cases the physician did not consult a second physician as required by law. One of these physicians (case 7) did not find this sort of consultation necessary because they did not consider it a clear case of euthanasia. Another (case 9) did not consider a consultation because it 'was a case of euthanasia outside the euthanasia law. No lethal drug was used'. These two physicians, however, did consult other physicians who, while not performing the tasks required by the law, gave advice and information. One physician (case 8) did not consult another physician at all because they found the legal consultation procedure too burdensome and not useful, and believed it was 'up to the patient and physician alone to make the decision'. Nor did they consult any other caregivers, as opposed to those who consulted additional physicians $(n=6)$ or caregivers such as nurses and palliative teams $(n=6)$ (data not in table).

In two out of the six cases, the physician consulted was not independent from the attending physician and from the patient. In one case (case 2), the physician knew the consultant because they had followed classes in palliative care together; in another (case 6), the consultant was a friend of the attending physician (data not in table).

Five cases were reported to the Federal Review Committee. One physician who did not report gave

\section{Box 2. Interview topics assessed in this study.}

Questions on the patient's medical situation during the final months of life, assessing:

- patient's main diagnosis;

- symptom burden in the last week of life using an adapted version of the Memorial Symptom Assessment Scale Global Distress Index (MSAS-GDI). ${ }^{19}$

Questions on the patient's medical situation at the time the decision to end life on explicit patient request was made, assessing:

- the extent to which the patient's medical situation was unavailing, without prospect of improvement;

- the extent to which there was constant and unbearable physical and/or psychological suffering that could not be alleviated; and

- whether or not curative, life-prolonging, or alternative palliative treatments could be considered that were not applied, and why these treatments were not applied.

Questions on information, consultation, and reporting of the euthanasia:

- whether or not the physician had informed the patient about their health condition and life expectancy;

- whether or not the physician had consulted (an)other physician(s), caregivers, and relatives of the patient; and

- whether or not the physician reported the case to the Federal Review Committee, and what the reasons were for reporting or not reporting the case.

Questions on the performance of euthanasia, assessing:

- the drugs used to perform euthanasia;

- the person who administered the drugs;

- the time between the administration of the first drug and death;

- technical problems during performance of euthanasia; and

- the life-shortening effect of the euthanasia.

as the reason that they had forgotten (case 6). Another said it was not a case of euthanasia but of terminal sedation with the intention of hastening death so did not have to be reported (case 7). The GP in case 8 did not report the case for the same reason that they did not consult a second physician. The physician in case 9 did not report it because they mistakenly thought that according to the law they should have waited for another 15 days (data not in table).

\section{Performance of euthanasia and drugs used}

In six cases, the physician performed euthanasia with a barbiturate: in combination with a neuromuscular relaxant $(n=4)$ and/or benzodiazepines $(n=2)$ (Table 3). In these cases, the patient died within seconds or minutes after the first drug was administered. In one case (case 5), a barbiturate was administered after the patient had been terminally sedated for several days.

In two cases (cases 8 and 9), the GP used opioids 


\begin{tabular}{|c|c|}
\hline Demographic characteristics & Number (total $n=9$ ) \\
\hline \multicolumn{2}{|l|}{ Age (years) } \\
\hline $1-17$ & 0 \\
\hline $18-64$ & 4 \\
\hline $65-79$ & 3 \\
\hline$\geq 80$ & 2 \\
\hline \multicolumn{2}{|l|}{ Sex } \\
\hline Male & 6 \\
\hline Female & 3 \\
\hline \multicolumn{2}{|l|}{ Educational level } \\
\hline Elementary or lower & 1 \\
\hline Lower secondary & 3 \\
\hline Higher secondary & 1 \\
\hline Higher education/university & 4 \\
\hline \multicolumn{2}{|l|}{ Estimated income } \\
\hline Low & 0 \\
\hline Average & 6 \\
\hline High & 3 \\
\hline \multicolumn{2}{|c|}{ Living with regular partner at time of death } \\
\hline Yes & 7 \\
\hline No & 2 \\
\hline \multicolumn{2}{|l|}{ Clinical characteristics } \\
\hline \multicolumn{2}{|l|}{ Main diagnosis } \\
\hline Cancer & 7 \\
\hline Multiple sclerosis & 1 \\
\hline Decompensated heart failure & 1 \\
\hline \multicolumn{2}{|l|}{ Global symptom distress ${ }^{a}$} \\
\hline Case 1 & 1.0 \\
\hline Case 2 & 2.0 \\
\hline Case 3 & 1.9 \\
\hline Case 4 & 1.2 \\
\hline Case 5 & 2.2 \\
\hline Case 6 & 1.1 \\
\hline Case 7 & 1.8 \\
\hline Case 8 & 1.0 \\
\hline Case 9 & 1.4 \\
\hline
\end{tabular}

aMeasured using the MSAS-GDI (scores out of a total of 4). Overall score per patient, representing global symptom distress, is the mean of the item scores for four psychological symptoms (frequency items for worry, sad, irritable, and nervous), and seven physical symptoms (distress items for lack of appetite, lack of energy, feeling drowsy, constipation, dry mouth, difficulty breathing, and pain).

with the explicit intention to hasten the patient's death. These patients died 24 and 48 hours respectively after the first drug was administered. In one case (case 7), the physician performed terminal sedation with the intention of hastening death using opioids in conjunction with a barbiturate. The patient died 3 days after the process of terminal sedation was begun.

In most cases, it was the GP who administered the final drug ( $n=8$ ); in one case, however (case 9), it was a nurse. Some GPs reported having had technical problems during the performance. One physician (case 5) reported difficulties finding a vein; another (case 9) revealed that the patient had unexpectedly woken up between the administering of the two drugs.

The life-shortening effect of the euthanasia was mostly estimated to be less than 1 month $(n=7)$. For two patients, the life-shortening effect was estimated as 1-6 months.

\section{DISCUSSION}

\section{Summary of main findings}

GPs in Belgium were interviewed about actual euthanasia cases in their practice, and their adherence to legal due care requirements was studied. In all cases, patients were in a condition for which medical treatment was unavailing and there was no prospect of improvement, and they had made an explicit, well-considered, and repeated request for euthanasia. However, procedural requirements such as the consultation of a second physician or the reporting of euthanasia were ignored in some cases. Euthanasia was most often performed with barbiturates and/or neuromuscular relaxants. During the interview, all but one physician labelled the end-of-life decision as euthanasia. Cases of euthanasia were least often reported to the Federal Review Committee when the physician did not consider them to be euthanasia, when they were performed with opioids, and when no legal consultation with another physician had taken place.

\section{Strengths and limitations of the study}

This study is the first to provide detailed information on actual euthanasia cases in Belgium, taking place at home under the care of a GP. Because data were gathered through extensive face-to-face interviews with GPs, the study offers unique and thorough information on a practice about which little scientific and medical information exists to date. The cases presented were identified via a large-scale retrospective mortality study representative of all deaths in Belgium, ${ }^{15}$ and are therefore likely to be representative of euthanasia cases at home in Belgium. The reliability of the surveillance system from which GPs were selected for interview has been demonstrated elsewhere. ${ }^{16-18}$ Recall bias was minimised, as interviews were conducted within a few months of the GP registering the case.

The study also has some limitations. During the 2year study period, only 11 cases of euthanasia were identified and an interview could be conducted in only nine of these. The study conclusions are thus based on a very small number of cases. Furthermore, the study is limited to euthanasia cases at home and cannot claim to be representative of euthanasia practice in hospitals or care homes. Future research could produce a sample from all care settings by identifying all euthanasia cases, including those in 
Table 2. GPs' adherence to legal due care requirements for euthanasia.

\begin{tabular}{|c|c|c|c|c|c|c|c|c|c|c|}
\hline & \multicolumn{9}{|c|}{ Case $^{a}$} & \multirow{2}{*}{$\begin{array}{l}\text { Total number of cases } \\
\text { in which requirement was met }\end{array}$} \\
\hline & 1 & 2 & 3 & 4 & 5 & 6 & 7 & 8 & 9 & \\
\hline \multicolumn{11}{|l|}{ Substantive requirements } \\
\hline Patient is $\geq 18$ years & + & + & + & + & + & + & + & + & + & 9 \\
\hline \multicolumn{11}{|l|}{ Request } \\
\hline $\begin{array}{l}\text { Voluntary, and not result of any } \\
\text { external pressure }\end{array}$ & + & + & + & + & + & + & + & + & + & 9 \\
\hline Explicit & + & + & + & + & + & + & + & + & + & 9 \\
\hline In writing & + & + & + & + & + & + & + & - & + & 8 \\
\hline Well-considered & + & + & + & + & + & + & + & + & + & 9 \\
\hline Repeated & + & + & + & + & + & + & + & + & + & 9 \\
\hline \multicolumn{11}{|l|}{ Medical condition } \\
\hline $\begin{array}{l}\text { Constant and unbearable physical } \\
\text { or psychological suffering }\end{array}$ & + & + & + & - & + & + & + & + & + & 8 \\
\hline $\begin{array}{l}\text { Resulting from serious and incurable } \\
\text { condition, caused by accident or illness }\end{array}$ & + & + & + & + & + & + & + & + & + & 9 \\
\hline Hopeless/no prospect of improvement & + & + & + & + & + & + & + & + & + & 9 \\
\hline $\begin{array}{l}\text { Total number of substantive } \\
\text { requirements met per case (maximum 9) }\end{array}$ & 9 & 9 & 9 & 8 & 9 & 9 & 9 & 8 & 9 & \\
\hline \multicolumn{11}{|l|}{ Procedural requirements } \\
\hline $\begin{array}{l}\text { Inform patient about health } \\
\text { condition and life expectancy }\end{array}$ & + & + & + & + & + & + & + & + & + & 9 \\
\hline \multicolumn{11}{|l|}{ Consultation } \\
\hline Second physician consulted & + & + & + & + & + & + & - & - & - & 6 \\
\hline $\begin{array}{l}\text { Second physician was independent } \\
\text { from patient and attending physician }\end{array}$ & + & - & + & + & + & - & NA & NA & NA & 4 \\
\hline $\begin{array}{l}\text { Report decision-making process } \\
\text { in medical file }\end{array}$ & + & + & - & + & - & - & + & + & + & 6 \\
\hline $\begin{array}{l}\text { Report case to Federal Control and } \\
\text { Evaluation Committee Euthanasia }\end{array}$ & + & + & + & + & + & - & - & - & - & 5 \\
\hline $\begin{array}{l}\text { Total number of procedural requirements } \\
\text { met per case (maximum 5) }\end{array}$ & 5 & 4 & 4 & 5 & 4 & 2 & 2 & 2 & 2 & \\
\hline $\begin{array}{l}\text { Total number of all requirements met } \\
\text { per case (maximum 14) }\end{array}$ & 14 & 13 & 13 & 13 & 13 & 11 & 11 & 10 & 11 & \\
\hline
\end{tabular}

hospital, via death certificates, and asking the involved physicians to be interviewed. Lastly, as interviews were conducted with GPs about their own adherence and non-adherence to the law, the possibility of social desirability bias cannot be excluded.

\section{Comparison with existing literature}

In five out of the nine cases, all or almost all legal due care requirements were met, indicating that the majority of physicians interviewed seemed to be aware of the importance of adhering to them in practice. However, in a few cases the procedural requirements concerning consultation of an independent physician and reporting of euthanasia were not met. The study suggests a number of possible reasons for this: the self-labelling of the act, the drugs used, lack of knowledge about legal requirements, and attitudes towards the law and towards control.
The study suggests that GPs are not always aware that they are engaging in an act that is legally regarded as euthanasia. When GPs are not aware that they are performing euthanasia, they will not feel obliged to comply with the law. This finding is in accordance with findings from the Netherlands..$^{23}$ For example, when asked during the interview whether the case was one of euthanasia, one GP preferred to call it terminal sedation with the explicit intention of hastening death. However, as official guidelines state, when a patient requests their life to be ended and the physician performs terminal sedation or administers opioids in doses higher than needed merely to alleviate pain or other symptoms, and with an explicit intention of hastening death, the act equals euthanasia and the same legal due care requirements as for euthanasia apply. ${ }^{24,25}$

Although four physicians used barbiturates and/or neuromuscular relaxants to perform euthanasia, ${ }^{26,27}$ some reported having used only opioids. Opioids 


\section{Table 3. Performance and life-shortening effect of euthanasia.}

\begin{tabular}{|c|c|c|c|c|c|c|c|c|c|}
\hline Case $^{a}$ & 1 & 2 & 3 & 4 & 5 & 6 & 7 & 8 & 9 \\
\hline $\begin{array}{r}\mathrm{Be} \\
\text { (IV } \\
+ \\
\text { (IV } \\
\text { (IV }\end{array}$ & $\begin{array}{l}\text { Benzodiazepine } \\
\text { (IV in } 1 \text { dosage) } \\
\text { + barbiturate } \\
\text { (IV continuous) } \\
\text { + narcotic } \\
\text { antagonist } \\
\text { (IV continuous) }\end{array}$ & $\begin{array}{c}\text { Barbiturate } \\
\text { (SCC) + } \\
\text { neuromuscular } \\
\text { relaxant } \\
\text { (IV continuous) }\end{array}$ & $\begin{array}{l}\text { Barbiturate } \\
\text { (IV } 1 \text { dosage) + } \\
\text { neuromuscular } \\
\text { relaxant (IV } \\
1 \text { dosage) }\end{array}$ & $\begin{array}{c}\text { Benzodiazepine } \\
\text { (IV } 1 \text { dosage) } \\
\text { + barbiturate } \\
\text { (IV } 1 \text { dosage) + } \\
\text { neuromuscular } \\
\text { relaxant } \\
\text { (IV } 1 \text { dosage) }\end{array}$ & $\begin{array}{c}\text { Opioid } \\
\text { (SCC) }+ \\
\text { benzodiazepine } \\
\text { (SCC) } \\
\text { + } \text { barbiturate }^{\mathrm{b}} \\
\text { (IV } 1 \text { dosage) }\end{array}$ & $\begin{array}{c}\text { Barbiturate } \\
\text { (IV } 1 \text { dosage) + } \\
\text { neuromuscular } \\
\text { relaxant } \\
\text { (IV } 1 \text { dosage) }\end{array}$ & $\begin{array}{c}\text { Opioid (TD } \\
\text { continuous) + } \\
\text { opioid (IV with } \\
\text { intervals) + } \\
\text { barbiturate } \\
\text { (IV continuous) }\end{array}$ & $\begin{array}{c}\text { Opioid } \\
\text { (SC with } \\
\text { intervals) }+ \\
\text { benzodiazepine } \\
\text { (SC with } \\
\text { intervals) }\end{array}$ & $\begin{array}{c}\text { Phenothiazine } \\
\text { (PO } 1 \text { dosage) } \\
\text { + opioid (TD } \\
\text { e continuous) } \\
\text { + opioid } \\
\text { (SCC) }\end{array}$ \\
\hline $\begin{array}{l}\text { Person who } \\
\text { administered } \\
\text { the last drug }\end{array}$ & Physician & Physician & Physician & Physician & Physician & Physician & Nurse & $\begin{array}{l}\text { Physician } \\
\text { a }\end{array}$ & $\begin{array}{l}\text { Physician, nurse, } \\
\text { and family together }\end{array}$ \\
\hline $\begin{array}{l}\text { Time between } \\
\text { administration first } \\
\text { drug and death }\end{array}$ & $\begin{array}{l}8 \text { minutes } \\
\text { st }\end{array}$ & 3 minutes & 1 minute & 1 minute & 5 seconds & 5 seconds & 3 days & 24 hours & 48 hours \\
\hline $\begin{array}{l}\text { Reported technical } \\
\text { problems during } \\
\text { performance }\end{array}$ & None & None & None & None & $\begin{array}{l}\text { Problem finding a } \\
\text { vein in which to } \\
\text { inject the drug }\end{array}$ & None & None & None & $\begin{array}{l}\text { Patient had woken } \\
\text { up between } \\
\text { administration } \\
\text { of two drugs }\end{array}$ \\
\hline $\begin{array}{l}\text { Estimated life- } \\
\text { shortening effect } \\
\text { of the euthanasia }\end{array}$ & 1-6 months & $1-4$ weeks & 1-7 days & 1-4 weeks & 1-4 weeks & $1-6$ months & 1-7 days & 1-4 weeks & 1-7 days \\
\hline
\end{tabular}

a Same case order as in Table 2. ${ }^{\mathrm{b}}$ The first drug to bring about death is in this case considered to be the barbiturate, as the other drugs were used to perform terminal sedation. The barbiturate was administered after the patient had been terminally sedated for 10 days. The patient died 5 days after the administration of the barbiturate. $I V=$ intravenous. $P O=$ oral. $S C=$ subcutaneous. SCC = subcutaneous continuous. $T D=$ transdermal.

are considered unsuitable for euthanasia because their effectiveness as lethal drugs is uncertain and there can be unwanted side-effects. ${ }^{9,26,27}$ GPs who used opioids felt either very reluctant to perform euthanasia or had a negative opinion about certain procedures of the euthanasia law. They may have chosen opioids because these drugs are not normally associated with euthanasia. By disguising the end-of-life decision as normal medical practice, whether deliberately or not, they may have felt they had granted their patient's wish without, in their eyes, having performed real euthanasia and without having to comply with the euthanasia law. When cases of euthanasia were performed with opioids or other non-recommended drugs, there was considerably less adherence to the procedural legal due care requirements. At present, the euthanasia law does not specify which drugs and which dosages should be used to perform euthanasia and uniform guidelines, such as those that exist in the Netherlands, ${ }^{26}$ are lacking in Belgium.

Physicians also sometimes fail to comply with the law because of lack of knowledge about the due care requirements or uncertainty about how the legal requirements must be interpreted. However, there were also indications in the interviews that physicians sometimes fail to adhere to due care requirements because of a negative attitude towards aspects of the law; certain legal requirements, such as consultation and reporting, are deemed too burdensome or unnecessary.

\section{Implications for clinical practice}

This study found that while most GPs adhered to the substantive requirements, some demonstrated limited adherence to the procedural requirements. Although legalisation of euthanasia in Belgium has changed it from a covert practice to a more societally controlled one, legalisation alone does not seem sufficient to guarantee due care. It seems warranted that legalisation of euthanasia, rather than being a final destination, should be seen as a starting point for further debate about standards and guidelines for careful end-of-life practice, and should go together with the proper education of, and provision of information to, all physicians potentially involved. Incorporation in medical education, feedback from the Federal Review Committee to reporting GPs about their medical actions, and accessible, adequate support for GPs who are confronted with an explicit request for euthanasia could help them in understanding which practices are regarded as euthanasia, and could help overcome their limited knowledge of the euthanasia law.

\section{Funding body}

Support for the study came from the Research Council of the Vrije Universiteit Brussel in Belgium (project GOA27 2003-2007) and the Institute for the Promotion of Innovation by Science and Technology in Flanders as a Strategic Basic Research project (SBO) (contract SBO IWT 050158) (2006-2010), as part of the 'Monitoring Quality of End-ofLife Care (MELC) Study'. The Belgian Sentinel Network of GPs is supported by the Flemish Ministry for Welfare, Public Health and Family and the Direction générale de la Santé du 
Ministère de la Communauté française. The researchers are independent from the funders.

\section{Ethics approval}

The Ethical Review Board of Brussels University Hospital approved the study protocol (reference 2004045).

\section{Competing interests}

All authors have stated that there are none.

\section{Acknowledgements}

The authors would like to thank Katrien Drieskens, MD (Vrije Universiteit Brussel) and Sabien Bauwens, MA (Brussels University Hospital), for their contributions in study conception and support in data collection; Jane Ruthven for English editing; and the participating Sentinel GPs for providing the study data. None of these persons received any compensation for their roles in the study.

\section{Discuss this article}

Contribute and read comments about this article on the Discussion Forum: http://www.rcgp.org.uk/bjgp-discuss

\section{REFERENCES}

1. Van der Heide A, Deliens L, Faisst K, et al, on behalf of the EURELD consortium. End-of-life decision-making in six European countries: descriptive study. Lancet 2003; 362(9381):345-350.

2. Meier D, Emmons CA, Wallenstein S, et al. A national survey of physician-assisted suicide and euthanasia in the United States. N Engl J Med 1998; 338(17): 1193-1201.

3. Wet betreffende euthanasie 28 mei, 2002. Belgisch Staatsblad 22 juni 2002. [Law concerning euthanasia May 28, 2002. Belgian official collection of the Laws 22 June 2002]. http://www.health.fgov.be/euthanasie (accessed 10 Dec 2009)

4. Deliens L, van der Wal G. The euthanasia law in Belgium and the Netherlands. Lancet 2003; 362(9391): 1239-1240.

5. Wet toetsing levensbeëindiging op verzoek en hulp bij zelfdoding 1 April, 2002. [Termination of Life on Request and Assisted Suicide (Review Procedures) Act 1 April 2002].

http://www.toetsingscommissieseuthanasie.nl/wetgeving (accessed 10 Dec 2009).

6. Loi du 16 Mars 2009 sur l'euthanasie et l'assistance au suicide [Law of March 16, 2009 on euthanasia and assisted-suicide]. http://www.legilux.public.lu/leg/a/archives/2009/0046/a046.pdf (accessed 10 Dec 2009)

7. Magnusson RS. Euthanasia: above ground, below ground. J Med Ethics 2004; 30(5): 441-446.

8. Van der Heide A, Van Delden JJM, van der Wal G. Doctor-assisted dying: what difference does legalisation make? Lancet 2004; 364 Suppl 1: $24-25$

9. Federale Controle- en Evaluatiecommissie euthanasie. Eerste verslag aan de wetgevende kamers 22 September 2002-31 December 2003. [Federal Control and Evaluation Committee on Euthanasia. First report to Parliament 22 September 2002-31 December 2003] [in Dutch and French].

http://www.senaat.be/www/?MIval=/index_senate\&MENUID=12420\& LANG=fr (accessed 10 Dec 2009).

10. Federale Controle- en Evaluatiecommissie voor Euthanasie. Tweede verslag aan de wetgevende kamers 1 Januari 2004-31 December 2005. [Federal Control and Evaluation Committee on Euthanasia. Second report to Parliament 1 January 2004-31 December 2005]. http://www.senaat.be/www/?MIval=/index_senate\&MENUID=124208 LANG=fr (accessed 10 Dec 2009).

11. Federale Controle- en Evaluatiecommissie voor Euthanasie. Derde verslag aan de wetgevende kamers 1 Januari 2006-31 December 2007. [Federal Control and Evaluation Committee on Euthanasia. Second report to Parliament 1 January 2006-31 Dec 2007].

http://www.senate.be/www/?MIval=/index_senate\&MENUID=124208
LANG $=$ fr (accessed 10 December 2009).

12. Deliens L, Mortier F, Bilsen J, et al. End-of-life decisions in medical practice in Flanders, Belgium: a nationwide survey. Lancet 2000; 356(9244): 1806-1811.

13. Cohen J, Bilsen J, Fischer S, et al, EURELD Consortium. End-of-life decision-making in Belgium, Denmark, Sweden and Switzerland: does place of death make a difference? J Epidemiol Community Health 2007; 61(12): 1062-1068.

14. Lemiengre J, Dierckx de Casterlé B, Verbeke G, et al. Ethics policies on euthanasia in hospitals. A survey in Flanders (Belgium). Health Policy 2007; 84(2-3): 170-180

15. Van den Block L, Van Casteren V, Deschepper R, et al. Nationwide monitoring of end-of-life care via the Sentinel Network of General Practitioners in Belgium: the research protocol of the SENTI-MELC study. BMC Palliat Care 2007; 6: 6 .

16. Lobet MP, Stroobant A, Mertens R, et al. Tool for validation of the network of sentinel general practitioners in the Belgian health care system. Int J Epidemiol 1987; 16(4): 612-618.

17. Stroobant A, Van Casteren V, Thiers G. Surveillance systems from primary-care data: surveillance through a network of sentinal general practitioners. In: Eylenbosch WJ, Noah D (eds). Surveillance in health and disease. Oxford: Oxford University Press, 1988; 62-74.

18. Boffin N, Bossuyt N, Van Casteren V. Current characteristics and evolution of the Sentinel General Practitioners: data gathered in 2005 [Huidige kenmerken en evolutie van de peilartsen en hun praktijk. Gegevens verzameld in 2005]. Report No.: IPH/EPI REPORTS N 2007 — 013. Scientific Institute of Public Health Belgium, Unit of Epidemiology, 2007.

http://www.iph.fgov.be/epidemio/epien/index10.htm (accessed 10 Dec 2009).

19. Hickman SE, Tilden VP, Tolle SW. Family reports of dying patients' distress: the adaptation of a research tool to assess global symptom distress in the last week of life. J Pain Symptom Manage 2001; 22(1): 565-574.

20. Klinkenberg M. The last phase of life of older people: health, preferences and care: a proxy report study. $\mathrm{PhD}$ thesis. Amsterdam: EMGO Institute, VU Amsterdam, 2003.

21. Deeg D, Beekman A, Kriegsman D, Westendorp-de Serière M. Autonomy and well-being in the aging population II: Report from the Longitudinal Aging Study Amsterdam 1992-1996. Amsterdam: VU University Press, 1998.

22. Van der Wal G, van der Heide A, Onwuteaka-Philipsen BD, van der Maas PJ. Medical decision-making at the end of life: practice in The Netherlands and the evaluation procedure of euthanasia. [Medische besluitvorming aan het einde van het leven: de praktiik en de toetsingsprocedure euthanasie]. Utrecht: De Tijdstroom Uitgeverij, 2003

23. Van der Heide A, Onwuteaka- Philipsen BD, Rurup M, et al. End-of-life practices in the Netherlands under the Euthanasia Act. N Engl J Med 2007; 356(19): 1957-1965.

24. Federale Controle- en Evaluatiecommissie voor Euthanasie. Informatiebrochure voor de artsen, 2006. [Federal Control and Evaluation Committee on Euthanasia. Information brochure for physicians, 2006].

http://www.senaat.be/www/?MIval=/index_senate\&MENUID=12420\& LANG $=$ fr (accessed 10 Dec 2009).

25. Royal Dutch Medical Association (KNMG). Perspective RDMA concerning euthanasia 2003 [Standpunt KNMG inzake euthanasia 2003]. http://knmg.artsennet.nl/web/file?uuid=8c5806df-66ba-4c8a9e68-95052c69a20f\&owner=a8a9ce0e-f42b-47a5-960ebe08025b7b04\&contentid=41999 (accessed 2 March 2010).

26. Royal Dutch Society for the Advancement of Pharmacy (KNMP). Utilization and preparations of euthanasia drugs [in Dutch]. The Hague: KNMP, 1998.

27. Battin MP, Lipman AG (eds). Drug use in assisted-suicide and euthanasia. New York: Haworth Press, 1996. 